\title{
Cameroonian Spice Extracts Modulate Molecular Mechanisms Relevant to Cardiometabolic Diseases in SW 872 Human Liposarcoma Cells
}

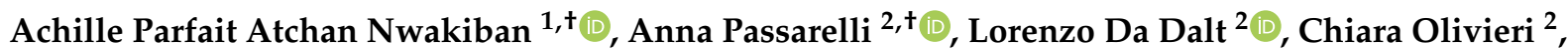 \\ Tugba Nur Demirci ${ }^{2}$, Stefano Piazza ${ }^{2}{ }^{\oplus}$, Enrico Sangiovanni ${ }^{2}\left({ }^{\circ}\right.$, Eugénie Carpentier-Maguire ${ }^{3}$, Giulia Martinelli ${ }^{2}$, \\ Shilpa Talkad Shivashankara ${ }^{4}$, Uma Venkateswaran Manjappara ${ }^{4}$, Armelle Deutou Tchamgoue ${ }^{5}$,

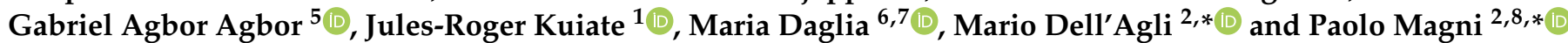

Citation: Atchan Nwakiban, A.P.; Passarelli, A.; Da Dalt, L.; Olivieri, C.; Demirci, T.N.; Piazza, S.; Sangiovanni, E.; Carpentier-Maguire, E.; Martinelli, G.; Shivashankara, S.T.; et al.

Cameroonian Spice Extracts Modulate Molecular Mechanisms Relevant to Cardiometabolic Diseases in SW 872 Human Liposarcoma Cells. Nutrients 2021, 13, 4271. https:// doi.org/ $10.3390 /$ nu13124271

Academic Editor: Flávio Reis

Received: 9 November 2021

Accepted: 25 November 2021

Published: 26 November 2021

Publisher's Note: MDPI stays neutral with regard to jurisdictional claims in published maps and institutional affiliations.

Copyright: (c) 2021 by the authors. Licensee MDPI, Basel, Switzerland. This article is an open access article distributed under the terms and conditions of the Creative Commons Attribution (CC BY) license (https:/ / creativecommons.org/licenses/by/ $4.0 /)$.
1 Department of Biochemistry, Faculty of Science, University of Dschang, Dschang P.O. Box 96, Cameroon; achilestyle@yahoo.fr (A.P.A.N.); jrkuiate@yahoo.com (J.-R.K.)

2 Department of Pharmacological and Biomolecular Sciences, Università degli Studi di Milano, 20133 Milan, Italy; anna.passarelli2393@gmail.com (A.P.); lorenzo.dadalt@unimi.it (L.D.D.); chia.olivieri@gmail.com (C.O.); tugba.demirci@studenti.unimi.it (T.N.D.); stefano.piazza@unimi.it (S.P.); enrico.sangiovanni@unimi.it (E.S.); giulia.martinelli@unimi.it (G.M.)

3 Department of Science and Technology, University of Lille, Rue de Lille, 59160 Lille, France; eugenie.carpentiermaguire@gmail.com

4 Department of Lipid Science, CSIR-Central Food Technological Research Institute (CFTRI), Mysore 570 020, India; shilpa25188@gmail.com (S.T.S.); umamanjappara@cftri.res.in (U.V.M.)

5 Institute of Medical Research and Medicinal Plants Studies (IMPM), Yaoundé 4123, Cameroon; armelle_d2002@yahoo.fr (A.D.T.); agogae@yahoo.fr (G.A.A.)

6 Department of Pharmacy, University of Naples Federico II, 80131 Naples, Italy; maria.daglia@unina.it

7 International Research Center for Food Nutrition and Safety, Jiangsu University, Zhenjiang 212013, China

8 IRCCS MultiMedica, Sesto San Giovanni, 20099 Milan, Italy

* Correspondence: mario.dellagli@unimi.it (M.D.); paolo.magni@unimi.it (P.M.);

Tel.: +39-0250318398 (M.D.); +39-0250318229 (P.M.)

+ These authors contributed equally to this work.

Abstract: The molecular pathophysiology of cardiometabolic diseases is known to be influenced by dysfunctional ectopic adipose tissue. In addition to lifestyle improvements, these conditions may be managed by novel nutraceutical products. This study evaluatedthe effects of 11 Cameroonian medicinal spice extracts on triglyceride accumulation, glucose uptake, reactive oxygen species (ROS) production and interleukin secretion in SW 872 human adipocytes after differentiation with $100 \mu \mathrm{M}$ oleic acid. Triglyceride content was significantly reduced by all spice extracts. Glucose uptake was significantly increased by Tetrapleura tetraptera, Aframomum melegueta and Zanthoxylum leprieurii. Moreover, Xylopia parviflora, Echinops giganteus and Dichrostachys glomerata significantly reduced the production of ROS. Concerning pro-inflammatory cytokine secretion, we observed that Tetrapleura tetraptera, Echinops giganteus, Dichrostachys glomerata and Aframomum melegueta reduced IL-6 secretion. In addition, Xylopia parviflora, Monodora myristica, Zanthoxylum leprieurii, and Xylopia aethiopica reduced IL-8 secretion, while Dichrostachys glomerata and Aframomum citratum increased it. These findings highlight some interesting properties of these Cameroonian spice extracts in the modulation of cellular parameters relevant to cardiometabolic diseases, which may be further exploited, aiming to develop novel treatment options for these conditions based on nutraceutical products.

Keywords: Cameroonian spice extracts; SW 872 adipocytes; triglyceride accumulation; glucose uptake; oxidative stress; pro-inflammatory cytokines

\section{Introduction}

The use of well-characterized nutraceutical products, in addition to lifestyle changes, is an interesting option for prevention and management of chronic cardiovascular and 
metabolic diseases, including obesity, type 2 diabetes mellitus (T2DM), atherosclerosis and the metabolic syndrome [1], especially in milder pathological conditions [2,3]. In this context, dysfunction of the adipose tissue and derangement of adipocyte biology play a pivotal role involving several pathophysiological mechanisms including insulin resistance, oxidative stress, and low-grade chronic inflammation. Interestingly, many plant extracts used in traditional medicine were found to mitigate obesity and related dysmetabolic conditions in in-vitro experimental models as well as in clinical studies [4]. Our research group, along with other researchers, has previously investigated the composition and the molecular effects of several spice extracts from Cameroonian plants commonly used in traditional medicine. In particular, we explored the ability of these extracts to modulate the activity of some enzymes relevant to the control of cardiometabolic functions [5], the antioxidant and anti-inflammatory activities by gastric epithelial cells [6] and glucose uptake and antioxidant activity in human HepG2 cells [7].

Based on this knowledge, in this study we extended the evaluation of some potentially useful effects of these Cameroonian spice extracts in the context of adipocyte biology and pathophysiology. To address this issue, we took advantage of human SW 872 human liposarcoma cells differentiated to adipocytes by oleic acid (OA) as the model system, which previously proved suitable for testing the in-vitro metabolic activities of plant-derived extracts [8]. More specifically, the present study aimed at assessing the effects of these spice extracts on triglyceride (TG) accumulation, glucose uptake modulation, antioxidant activity and regulation of pro-inflammatory cytokine release.

\section{Materials and Methods}

\subsection{Chemicals}

Bovine insulin (Cat. No. I6634), oleic acid (OA) (Cat. No. O1257), ( \pm )-6-Hydroxy 2,5,7,8 tetramethylchromane-2-carboxylic acid (Trolox) (Cat. No. 93510), dimethylsulfoxide (DMSO) (Cat. No. D8418), metformin hydrochloride (Cat. No. M0605000), epigallocatechin gallate (EGCG) (Cat. No. E4143), 2-deoxy-2-[(7-nitro-2,1,3-benzoxadiazol-4-yl) amino]-Dglucose (2-NBDG) (Cat. No. N13195) and resveratrol (Cat. No. R5010) were obtained from Merck Life Science (Readington, NJ, USA).

5-(and-6)-chloromethyl-2', $7^{\prime}$-dichlorodihydrofluorescein diacetate (CM-H2DCFDA) (Cat. No. C6827) was obtained from Thermo Fisher Scientific (Waltham, MA, USA). Fetal Bovine Serum (FBS) (Cat. No. ECS0180L) (Euroclone, Milan, Italy).

\subsection{Preparation of Plant Extracts}

Plant material comprised 11 spices (Xylopia aethiopica (Dunal) A.Rich., Xylopia parviflora (A. Rich) Benth, Scorodophloeus zenkeri Harms, Echinops giganteus A.Rich., Monodora myristica (Gaertn.) Dunal, Tetrapleura tetraptera (Schum. \& Thonn.) Taub., Dichrostachys glomerata (Forssk.) Chiov., Afrostyrax lepidophyllus Mildbr., Aframomum melegueta K.Schum., Aframomum citratum (C.Pereira) K.Schum., and Zanthoxylum leprieurii Guill. \& Perr.) harvested in different sites of the region of West Cameroon. Samples included fruits, seeds and roots, as identified in the National Herbarium of Cameroon (https: / irad.cm/index.php/fr/, accessed on 14 October 2021) in Yaoundé (Cameroon) compared to the deposited specimens. The preparation of the hydroethanolic extracts was conducted as previously reported [5]. Briefly, air-dried and powdered samples (100 g) were extracted using a 70\% hydroethanolic mixture at room temperature and in dark conditions. The mixture was filtered, concentrated under reduced pressure, and frozen to give crude extracts. They were then lyophilized and stored at $-20^{\circ} \mathrm{C}$. Spice extract stock solutions $(100 \mathrm{mg} / \mathrm{mL})$ dissolved in DMSO were prepared, aliquoted, and kept at $-80^{\circ} \mathrm{C}$. The stock solution of spice extracts in DMSO was diluted in culture medium to the appropriate concentrations for cell treatments. For more details, please check Table 1 in [7]. The same concentration of DMSO (in any case never exceeding $0.1 \%$ ) was also added to all control cultures. 
Table 1. Triglyceride accumulation in differentiated SW 872 adipocytes: effect of spice extracts.

\begin{tabular}{cccc}
\hline & Oleic Acid $\mathbf{( 1 0 0 \mu \mathrm { M } )}$ & \multicolumn{2}{c}{$\begin{array}{c}\text { Triglyceride } \\
\text { (\% of Oleic Acid-Treated Cells) }\end{array}$} \\
\hline & & $+24 \mathrm{~h}$ & $+48 \mathrm{~h}$ \\
undifferentiated control & - & $49.6 \pm 4.1 * * *$ & $64 \pm 0.7 * *$ \\
differentiated control & + & 100 & 100 \\
resveratrol $(10 \mu \mathrm{M})$ & + & $94.9 \pm 5.9$ & $69.6 \pm 3.0^{* * *}$ \\
Xylopia aethiopica & + & $96.5 \pm 7.6$ & $85.5 \pm 2.3^{*}$ \\
Xylopia parviflora & + & $88.2 \pm 1.0$ & $86.2 \pm 1.6^{*}$ \\
Scorodophloeus zenkeri & + & $97.9 \pm 9.6$ & $81.5 \pm 4.9^{*}$ \\
Monodora myristica & + & $90.4 \pm 9.0$ & $84.7 \pm 3.2^{*}$ \\
Tetrapleura tetraptera & + & $90.9 \pm 4.5$ & $86.2 \pm 2.2^{*}$ \\
Echinops giganteus & + & $104.2 \pm 5.9$ & $88.7 \pm 0.9 *$ \\
Afrostyrax lepidophyllus & + & $102.5 \pm 6.4$ & $83.5 \pm 10.1^{*}$ \\
Dichrostachys glomerata & + & $102.6 \pm 2.5$ & $82.6 \pm 6.8^{*}$ \\
Aframomum melegueta & + & $104 \pm 5.2$ & $87.0 \pm 4.7^{*}$ \\
Aframomum citratum & + & $98.3 \pm 4.7$ & $84 \pm 1.8^{*}$ \\
Zanthoxylum leprieurii & + & $98.5 \pm 8.8$ & $86.6 \pm 5.9 *$ \\
\hline
\end{tabular}

All spice extracts were used at $10 \mu \mathrm{g} / \mathrm{mL}$. Data are expressed as \% of oleic acid-treated cells taken as 100 mean $\pm \mathrm{SD}, n=3,(p<0.05)$ (one-way ANOVA multiple comparison); ${ }^{*} p<0.05,{ }^{* * *} p<0.001$ vs. the differentiated control group.

\subsection{Cell Cultures and Differentation}

The SW 872 human liposarcoma (ATCC ${ }^{\circledR}$ HTB-92 ${ }^{\mathrm{TM}}$ ) cell line was from the American Type Culture Collection (ATCC ${ }^{\circledR}$, Manassas, VA, USA) and grown as recommended. Cells were cultured in DMEM-F12 culture medium with L-Glutamine and HEPES $25 \mathrm{mM}$ supplemented with $10 \%$ fetal bovine serum (FBS), $1 \%$ penicillin $(100 \mathrm{U} / \mathrm{mL})$, and streptomycin $(100 \mu \mathrm{g} / \mathrm{mL})$. They were kept in culture in $100-\mathrm{mm}$ diameter Petri dishes at $37{ }^{\circ} \mathrm{C}$ in a humidified atmosphere containing $5 \% \mathrm{CO}_{2}$. Once they reached $80100 \%$ confluence, SW 872 cells were treated with $100 \mu \mathrm{M}$ OA to initiate cellular differentiation into adipocytes [9,10].

\subsection{Oil-Red-O Staining}

To assess intracellular lipid accumulation (a marker of adipocyte differentiation) of SW 872 cells, we used the Oil-red-O (ORO) staining. SW 872 cells were seeded in 24-well plates, were allowed to adhere until $90-100 \%$, confluence and then were treated with $100 \mu \mathrm{M}$ OA for 7 days. After medium removal, cells were washed with phosphate-buffered saline (PBS) and fixed with $4 \%$ formaldehyde in PBS for $1 \mathrm{~h}$ (room temperature). ORO working solution $(0.2 \%$ ORO in $40 \%$ isopropanol) was added to the culture dish and incubated at room temperature for $20 \mathrm{~min}$. After a wash with sterile distilled water, cell images were collected with a light microscope (ZEISS, Milan, Italy).

\subsection{MTS (3-(4,5-Dimethylthiazol-2-yl)-5-(3-carboxymethoxyphenyl)-2-(4-sulfophenyl)-2H- tetrazolium) Cell Viability Assay}

Cell viability assay [11] was performed using the Cell Titer 96 aqueous non-radioactive cell proliferation assay (Promega, Madison, WI, USA) following the method previously described [12] with minor modifications. Briefly, SW 872 cells were seeded in a sterile, flat-bottom 96-well plate at a density of $2 \times 10^{5}$ cells/well and incubated at $37^{\circ} \mathrm{C}$ for $24 \mathrm{~h}$ in a humidified incubator containing $5 \% \mathrm{CO}_{2}$. Extracts at different concentrations $(1,10,25$, 50 , and $100 \mu \mathrm{g} / \mathrm{mL}$ ) were prepared in fresh serum-free DMEM-F12 medium and $100 \mu \mathrm{L}$ of each treatment was added to each well and then incubated for 24 and $48 \mathrm{~h}$. Subsequently, $20 \mu \mathrm{L}$ of the MTS reagent in combination with the electron coupling agent phenazine methosulfate was added to each well and allowed to react for $1 \mathrm{~h}$ at $37^{\circ} \mathrm{C}$. After $2 \mathrm{~min}$ of shaking at lowest intensity, the absorbance at $490 \mathrm{~nm}$ was measured (EnSpire PerkinElmer Multimode Plate Reader). In the same conditions, controls and blanks, consisting of 
cells with media containing DMSO $(\leq 0.1 \%)$ and wells containing media without cells, respectively, were performed. The cell viability values were determined using the equation:

$$
\% \text { cell viability }=\left(\frac{\text { mean sample absorbance }- \text { mean blank absorbance }}{\text { mean control absorbance }- \text { mean blank absorbance }}\right) \times 100
$$

Three separate experiments run in triplicate replicates were conducted.

\subsection{Morphological Analysis}

Cells were cultured in sterile, flat-bottom 6- $\mathrm{cm}^{2}$ dishes for $24 \mathrm{~h}$. Different concentrations of extracts $(1,10,20$ and $100 \mu \mathrm{g} / \mathrm{mL})$ were prepared in serum-free media and $2 \mathrm{~mL}$ of each treatment was added to each dish and incubated for $24 \mathrm{~h}$ and $48 \mathrm{~h}$. After treatment, cells were visualized with a light microscope (ZEISS, Milan, Italy) using $10 \times, 20 \times$ and $32 \times$ magnifications.

\subsection{Interleukin-6 and Interleukin-8 Measurement}

Interleukin-6 (IL-6) and interleukin-8 (IL-8) medium content was quantified using human IL-6 and IL-8 ELISA kits, as previously described [13]. Briefly, Corning 96-well EIA/RIA plates from Merck Life Science (Milan, Italy) were coated with the antibody provided in the ELISA Kit (Peprotech, London, UK) overnight at $4{ }^{\circ} \mathrm{C}$. After blocking the reaction, $200 \mu \mathrm{L}$ of samples in duplicate were transferred into wells and incubated at room temperature for $1 \mathrm{~h}$. The amount of IL-6 and IL-8 in the samples was detected by the EnSpire Plate Reader (signal read: $450 \mathrm{~nm}, 0.1 \mathrm{~s}$ ) using biotinylated and streptavidinHRP conjugate antibodies, evaluating the $3,3^{\prime}, 5,5^{\prime}$ tetramethylbenzidine (TMB) substrate reaction. Quantification of IL-6 and IL-8 was done using an optimized standard curve provided with the ELISA Kit $(8.0-1000.0 \mathrm{pg} / \mathrm{mL})$. Resveratrol $(10 \mu \mathrm{M})$ and EGCG $(40 \mu \mathrm{M})$ were used as positive control for IL-6 and IL-8, respectively.

\subsection{Triglyceride Content Measurement}

To determine the accumulation of TG in the cells we used a sensitive assay using a TG quantification reagent (Vaktro Scientific, Patras, Greece). In this assay, TG are converted to free fatty acids and glycerol. Then, glycerol is oxidized to generate a colorimetric $(570 \mathrm{~nm}) /$ fluorometric $(\lambda \mathrm{ex}=535 \mathrm{~nm} / \lambda \mathrm{em}=587 \mathrm{~nm})$ product. The kit can detect 2 pmole10 nmole $(2-10,000 \mu \mathrm{M}$ range) of TG. All samples and standards were measured in duplicate. The data obtained were interpolated in an appropriate triglycerides standard curve after background correction.

\subsection{Measurement of ROS Production}

The ntracellular ROS level in SW 872 cells were determined by a fluorometric assay, applying the oxidant-sensitive fluorescence probe $\mathrm{CM}-\mathrm{H}_{2}$ DCFDA according to the method described by Piazza et al. [14]. Cells were seeded in 96-well black plates at a density of $2 \times 10^{5}$ cells/well, and after reaching $90 \%$ confluence, differentiated as previously described for 7 days with $100 \mu \mathrm{M}$ oleic acid. Further, they were incubated with plant extracts at different concentrations ranging from 0 to $20 \mu \mathrm{g} / \mathrm{mL}$ for $24 \mathrm{~h}$. Cells were then treated with $20 \mu \mathrm{M} \mathrm{CM}-\mathrm{H}_{2}$ DCFDA and then incubated for $1 \mathrm{~h}$ with $500 \mu \mathrm{M}$ hydrogen peroxide to induce ROS production. The resulting fluorescence intensities were quantified at an excitation wavelength of $485 \mathrm{~nm}$ and an emission wavelength of $535 \mathrm{~nm}$ using the EnSpire Plate Reader (Perkin Elmer, Milan, Italy).

\subsection{Glucose Uptake FACS Analysis}

Differentiated and non-differentiated SW 872 cells were cultured in 12-well plates in DMEM F- $12+10 \%$ FBS. After reaching about $80 \%$ confluence, cells were incubated with spice extracts $(10-20 \mu \mathrm{g} / \mathrm{mL})$ or insulin at different timing and concentrations. After incubation, cells were washed with PBS and treated with $20 \mu \mathrm{M}$ 2-NBDG for $30 \mathrm{~min}$ in MEM 
Eagle w/Earle's BSS without glucose. Finally, the 2-NBDG uptake was measured detecting the emitted fluorescence with FACS (BD LSRFortessa ${ }^{\mathrm{TM}}$ Flow Cytometer, Milan, Italy).

\subsection{Western Blotting Analysis}

Total protein extracts from SW 872 cells were obtained by lysing cells in $150 \mu \mathrm{L}$ RIPA buffer containing a mix of protease and phosphatase inhibitors (Roche Diagnostics, Monza, Italy). Forty $\mu \mathrm{g}$ of proteins and a molecular mass marker (Nove ${ }^{\circledR}$ Sharp Protein Standard, InvitrogenTM; Life Technologies, Monza, Italy) were separated on $10 \%$ sodium dodecylsulfate-polyacrylamide gel (SDS-PAGE) under denaturing and reducing conditions. They were then transferred to a nitrocellulose membrane by using the iBlotTM Gel Transfer Device (InvitrogenTM; Life Technologies). The membranes were washed with Tris-Buffered Saline-Tween 20 (TBS-T) and non-specific binding sites were blocked in TBS-T containing $5 \%$ BSA (Merck Life Science, Milan, Italy) or non-fat dried milk at room temperature for $60 \mathrm{~min}$. The blots were incubated overnight at $4{ }^{\circ} \mathrm{C}$ with anti-pAKT(Ser473), (1:150; Millipore, Merck Life Science), anti-AKT (1:1000; Cell Signaling Technology, Milan, Italy), and anti $\beta$-Actin (Millipore, diluted 1:5000) (5\% BSA or non-fat dried milk). Membranes were washed with TBS-T and then exposed for $30 \mathrm{~min}$ at room temperature to a diluted solution ( $5 \%$ non-fat dried milk) of the secondary antibodies. Immunoreactive bands were detected by exposure of the membranes to ClarityTM Western ECL chemiluminescent substrates (Bio-Rad Laboratories, Segrate, Italy) for $5 \mathrm{~min}$ and images were acquired with a ChemiDocTM XRS System (Bio-Rad Laboratories, Milan, Italy). Densitometric readings were assessed using the ImageLab software(6.1 version, Bio-Rad Laboratories, Milan, Italy).

\subsection{Statistical Analysis}

Results from at least three independent experiments carried out in triplicate were expressed as mean $\pm \mathrm{SD}$, values or as a mean percentage (\%) compared to a control. Graphs and data were analyzed using GraphPad Prism version 8 . The statistical analysis was made with one-way ANOVA followed by Tukey test, considering statistically significant $p<0.05$.

\section{Results}

\subsection{Spice Extracts up to $25 \mu \mathrm{g} / \mathrm{mL}$ Do Not Affect SW 872 Cell Viability and Morphology}

Preliminary experiments were conducted to assess the effect of 11 Cameroonian spice extracts on the viability of differentiated SW 872 cells by MTS assay and morphological analysis. The extraction protocol, molecular composition, and potential cytotoxic effects in other cell lines of the spice extracts used in this study have been previously reported [5-7]. The MTS assay was conducted after treatment with different concentrations $(1-100 \mu \mathrm{g} / \mathrm{mL})$ of extracts for $24 \mathrm{~h}$ and $48 \mathrm{~h}$. Viability threshold was set at $80 \%$ [15]. All spice extracts incubated for $24 \mathrm{~h}$ or $48 \mathrm{~h}$ proved non toxic up to the concentration of $25 \mu \mathrm{g} / \mathrm{mL}$ (Figure S1). More specifically, after $24 \mathrm{~h}$ of incubation, $6 / 11$ extracts proved toxic at $50 \mu \mathrm{g} / \mathrm{mL}$ and after $48 \mathrm{~h} 2 / 11$ plants were toxic already at $25 \mu \mathrm{g} / \mathrm{mL}$. Toxicity at $100 \mu \mathrm{g} / \mathrm{mL}$ was observed for 10/11 extracts in SW 872 cells, independently of the incubation time (Figure S1). We also investigated whether spice extracts affected cell morphology in addition to viability. The morphology of differentiated SW 872 cells was not affected by treatment for $24 \mathrm{~h}$ and $48 \mathrm{~h}$ with $1-25 \mu \mathrm{g} / \mathrm{mL}$ spice extracts. At $100 \mu \mathrm{g} / \mathrm{mL}$, the maximum concentration tested, all but one (A. lepidophyllus) spice extracts produced morphological changes, including cell death, rounding, and shrinking (representative images obtained with X. aethiopica and A. lepidophyllus extracts are shown in Figure S2). Based upon these results obtained by MTS assay and morphological analysis, all treatments with spice extracts were conducted for $24 \mathrm{~h}$ or $48 \mathrm{~h}$ at the concentration of $20 \mu \mathrm{g} / \mathrm{mL}$ or lower.

\subsection{All Spice Extracts Reduce Triglyceride Accumulation in Differentiated Adipocytes}

SW 872 cells were differentiated to adipocytes with $100 \mu \mathrm{M}$ OA for seven days, according to a previously published protocol $[8,9]$. This treatment led to a marked intracellular lipids accumulation, as observed by ORO staining analysis (Figure 1) and quantification 
of TG content (Table 1), indicating the acquisition of a mature adipocyte phenotype. Of interest, differentiation with OA resulted in a doubling of TG accumulation $(p<0.05)$, compared to untreated cells (Table 1). We then assessed whether treatment with spice extracts was able to modulate TG accumulation in differentiated SW 872 cells, which were treated for $24 \mathrm{~h}$ and $48 \mathrm{~h}$ with spice extracts (all at $10 \mu \mathrm{g} / \mathrm{mL}$ ). TG content did not change after a $24 \mathrm{~h}$ exposure to extracts. However, after $48 \mathrm{~h}$, all extracts were able to significantly $(p<0.05)$ decrease TG accumulation $(-11.3 \% /-18.5 \%)$. Resveratrol $(10 \mu \mathrm{M})$, taken as active control, significantly $(p<0.05)$ reduced TG accumulation by $30.4 \%$ (Table 1$)$. We then assessed whether treatment with spice extracts was able to modulate TG accumulation in differentiated SW 872 cells, which were treated for $24 \mathrm{~h}$ and $48 \mathrm{~h}$ with spice extracts (all at $10 \mu \mathrm{g} / \mathrm{mL}$ ). TG content did not change after a $24 \mathrm{~h}$ exposure to extracts. However, after $48 \mathrm{~h}$, all extracts were able to significantly $(p<0.05)$ decrease TG accumulation $(-11.3 \% /-18.5 \%)$. Resveratrol $(10 \mu \mathrm{M})$, taken as active control, significantly $(p<0.05)$ reduced TG accumulation by $30.4 \%$ (Table 1 ).
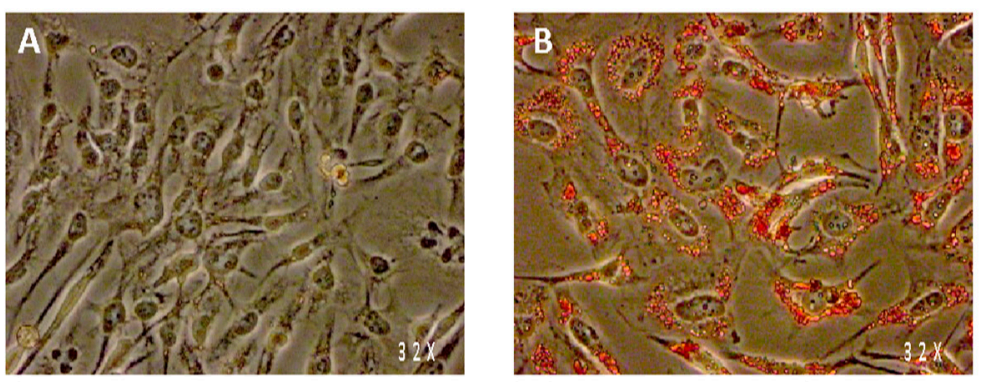

Figure 1. Intracellular lipid content (Oil-red-O staining) of SW 872 cells after 7 days of incubation without any treatment (A) or with $100 \mu \mathrm{M}$ oleic acid (B).

3.3. Tetrapleura tetraptera, Aframomum melegueta and Zanthoxylum leprieurii Increase Glucose Uptake in Differentiated Adipocytes

Glucose uptake is a pivotal event of adipocyte biology [16] and was assessed here in both undifferentiated and differentiated SW 872 cells by FACS analysis, measuring the uptake of 2-NBDG. Basal glucose uptake was significantly reduced ( $-54.8 \%$ vs controls; $p<0.001$ ) upon OA-differentiation compared to undifferentiated controls (Figure 2A). Insulin-activated glucose uptake was assessed according to time-course (15-60 min) and dose-response $(10 \mathrm{nM}-1 \mu \mathrm{M})$ parameters (Figure S3A,B). A significant increase of glucose uptake was however observed in differentiated cells after $60 \mathrm{~min}$ incubation with 10 $\mathrm{nM}(+16.8 \% ; p<0.05)$ and $100 \mathrm{nM}(+18.8 \% ; p<0.01)$ insulin (Figure S3B). The uptake of 2-NBDG was significantly $(p<0.001)$ increased by $T$. tetraptera $(+40.8 \%)$, A. melegueta $(+41.7 \%)$ and Z. leprieurii ( $+56.6 \%)$, all at the concentration of $10 \mu \mathrm{g} / \mathrm{mL}$ (Figure $2 \mathrm{~B}, \mathrm{C})$. This increment was even greater than that elicited by $100 \mathrm{nM}$ insulin $(+18.8 \% ; p<0.01)$. To test whether such increase was dose dependent, we selected the three most effective extracts and added $S$. zenkeri since in preliminary experiments this spice extract was effective at $20 \mu \mathrm{g} / \mathrm{mL}$ (Figure 2D).

We then explored the activation of the Akt signalling pathway, known to be associated with insulin receptors, under non-differentiated and OA-differentiated conditions and observed that $100 \mathrm{nM}$ insulin treatment elicited a rapid and prolonged phosphorylation of Akt in OA-differentiated cells but not in non-differentiated cells (Figure 3A). This insulindriven activation of Akt was not affected by a 24-h pretreatment of SW 872 cells with the three extracts that were found more effective in promoting glucose uptake (A. melegueta, Z. leprieurii, and T. tetraptera) (Figure 3B). 


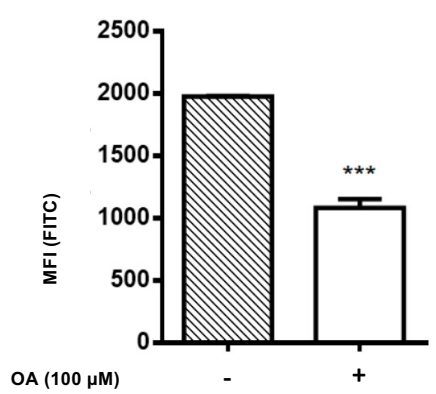

C

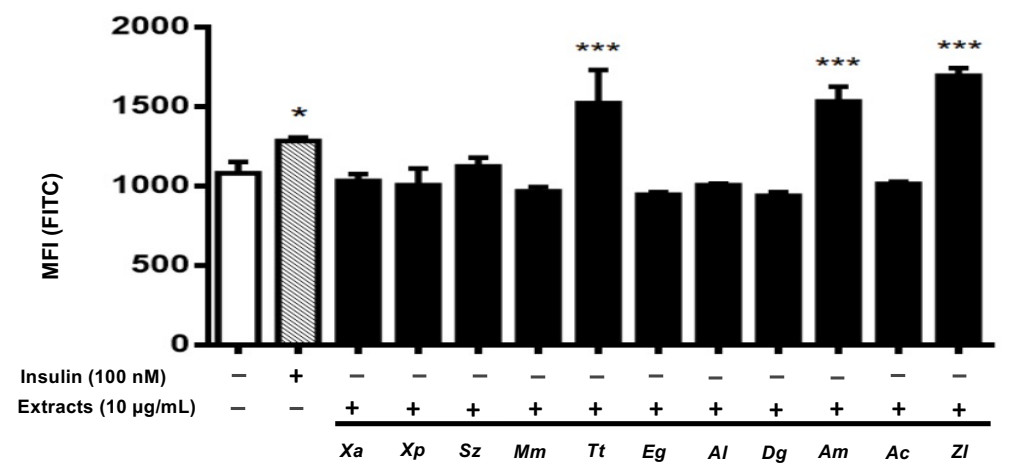

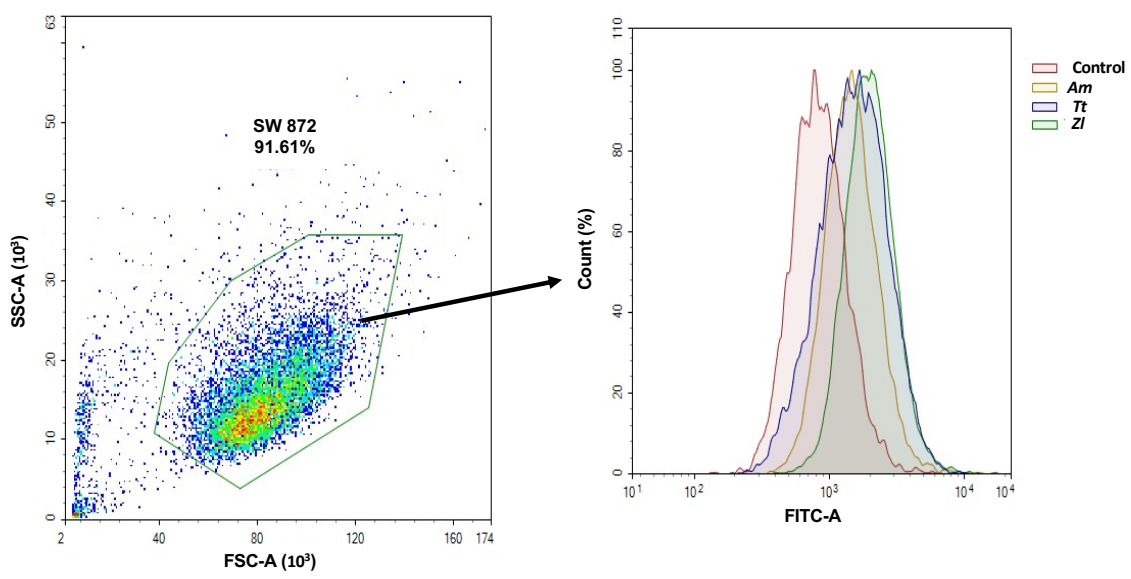

D

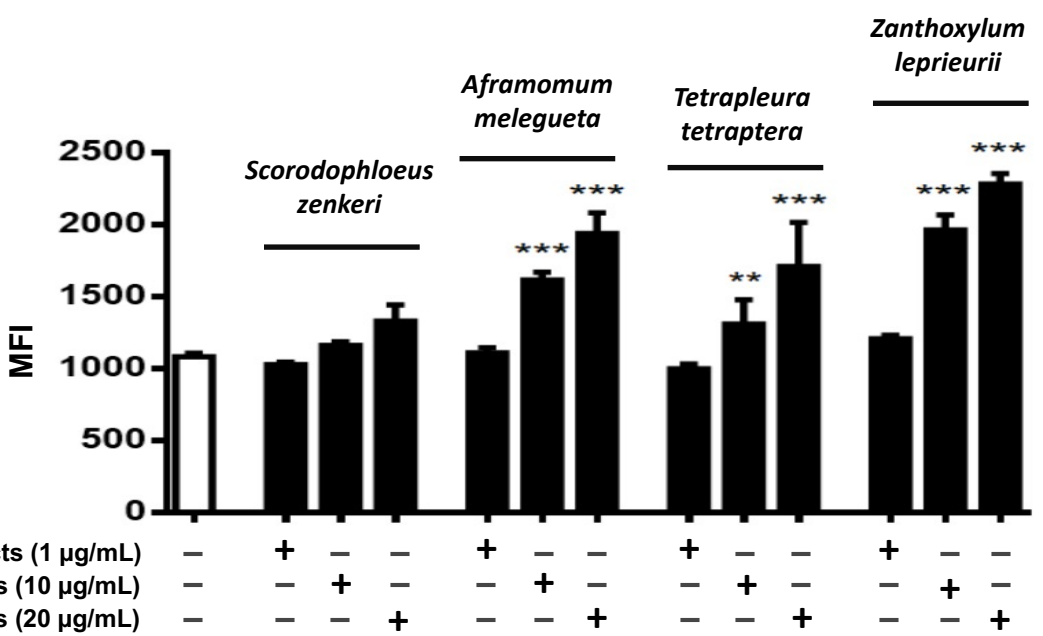

Figure 2. Glucose uptake in SW 872 cells treated with spice extracts. (A) Basal glucose uptake in non-differentiated and differentiated cells $(100 \mu \mathrm{M} \mathrm{OA}) ;{ }^{* * *} p<0.001$ (unpaired $t$-test). (B) Differentiated cells were incubated for $1 \mathrm{~h}$ with $100 \mathrm{nM}$ insulin or treated for $24 \mathrm{~h}$ with $10 \mu \mathrm{g} / \mathrm{mL}$ of each spice extract. Xa, Xylopia aethiopica; Xp, Xylopia parviflora; Sz, Scorodophloeus zenkeri; Mm, Monodora myristica; Tt, Tetrapleura tetraptera; Eg, Echinops giganteus; Al, Afrostyrax lepidophyllus; Dg, Dichrostachys glomerata; Am, Aframomum melegueta; Ac, Aframomum citratum; Zl, Zanthoxylum leprieurii. ${ }^{*} p<0.05,{ }^{* * *} p<0.001$. (C) Mean fluorescence intensity (MFI) of FACS analysis obtained in differentiated SW 872 cells by treatment with Aframomum melegueta $(\mathrm{Am})$, Zanthoxylum leprieurii $(\mathrm{Zl})$ and Tetrapleura tetraptera $(\mathrm{Tt})$. The control (red area) is represented by differentiated SW 872 cells MFI. (D) Differentiated cells were treated for $24 \mathrm{~h}$ with the indicated extracts at 1-10-20 $\mu \mathrm{g} / \mathrm{mL}$. Glucose uptake was assessed in SW 872 cells by FACS analysis. One experiment $(n=3)$ is shown as representative of 3 separated experiments, each in triplicate. Results are expressed as mean $\pm \mathrm{SD}$. ${ }^{* *} p<0.01,{ }^{* * *} p<0.001$ (one-way ANOVA multiple comparison). 


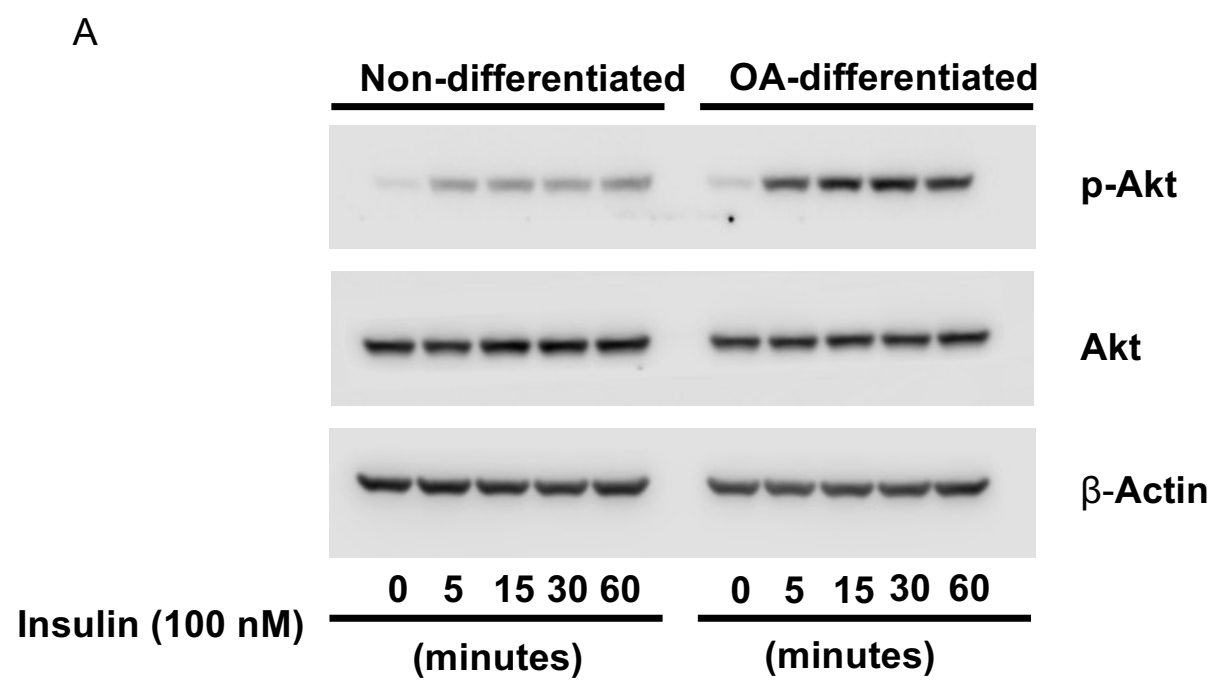

B
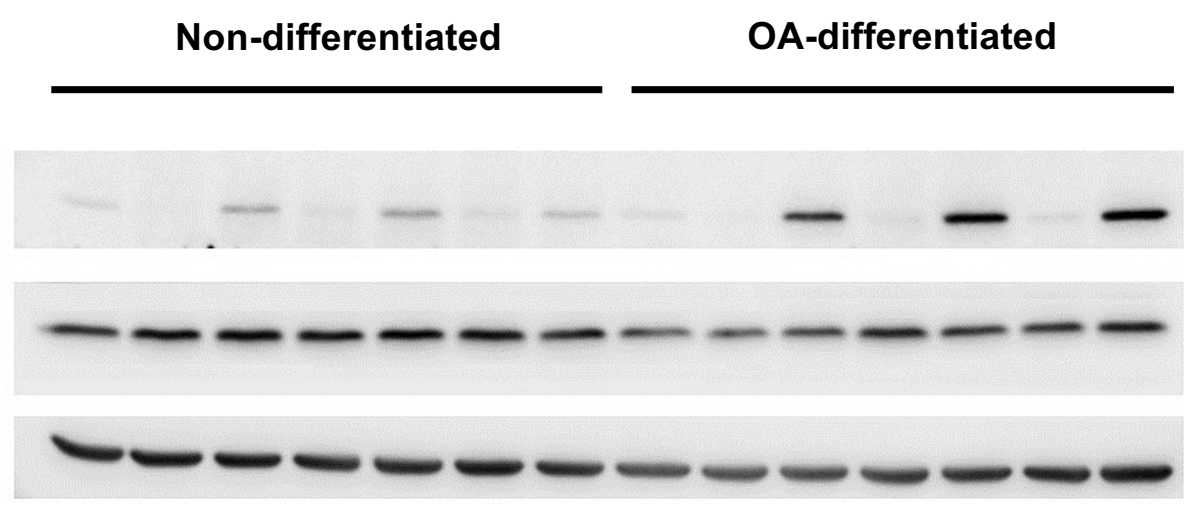

p-Akt

Akt

$\beta$-Actin

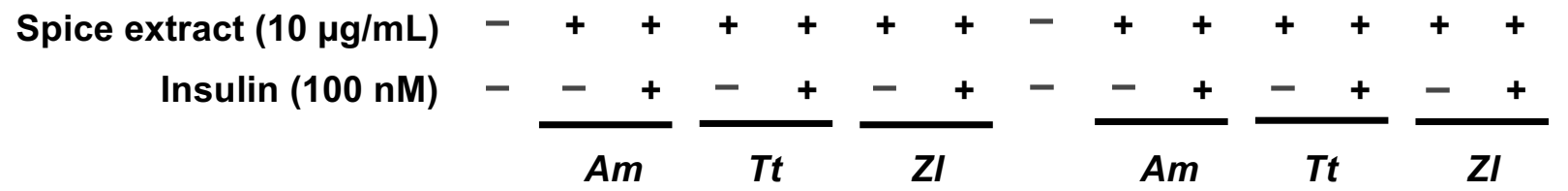

Figure 3. Akt phosphorylation dynamics in differentiated and non-differentiated SW 872 cells. (A) Time course of Akt phosphorylation upon treatment with $100 \mathrm{nM}$ insulin. (B) Combined effect of 24-h exposure to $10 \mu \mathrm{g} / \mathrm{mL}$ spice extracts (A. melegueta $(\mathrm{Am}), \mathrm{Z}$. leprieurii $(\mathrm{Zl})$ and T. tetraptera $(\mathrm{Tt})$ ) and 1-h treatment with $100 \mathrm{nM}$ insulin on Akt phosphorylation.

\subsection{Spice Extracts Modulate IL-6 and IL-8 Release from Differentiated Adipocytes}

The release of pro-inflammatory cytokines, like IL-6 and IL-8, is a central pathophysiological feature of disfunctional adipocytes [17]. OA-differentiation of SW 872 cells resulted in a significant $(p<0.001)$ increase of IL-6 release (Figure 4A), which was significantly reduced by exposure $(24 \mathrm{~h}, 10 \mu \mathrm{g} / \mathrm{mL})$ to $A$. melegueta $(-43.1 \% ; p<0.001), D$. glomerata $(-39.9 \% ; p<0.001)$, T. tetraptera $(-29.7 \% ; p<0.05)$ and E. giganteus $(-29 \% ; p<0.05)$ (Figure 4B). Resveratrol, selected as positive control, resulted in a $67.5 \%(p<0.001)$ reduction (Figure 4B). Conversely, IL-8 release was significantly reduced $(p<0.01)$ upon OA-differentiation of SW 872 cells (Figure 4C). IL-8 secretion was further decreased by exposure to X. parviflora, $(-36.8 \% ; p<0.001)$, X. aethiopica $(-21.1 \% ; p<0.05)$, M. myristica $(-24.3 \% ; p<0.01)$ and Z. leprieurii $(-32.7 \% ; p<0.01)$ (Figure $4 \mathrm{D})$. On the contrary, treatment with $D$. glomerata and A. citratum resulted in a marked increase of IL- 8 release $(+58.6 \%$ and $+78.7 \%$, respectively; $p<0.001$ ). 


\section{Interleukin-6}

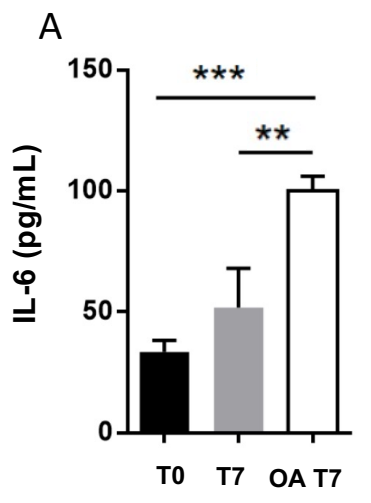

\section{Interleukin-8}

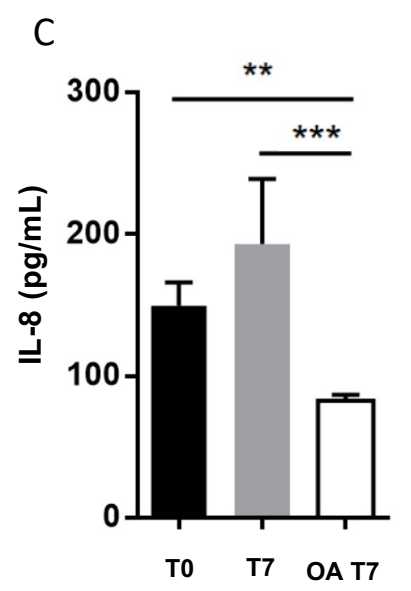

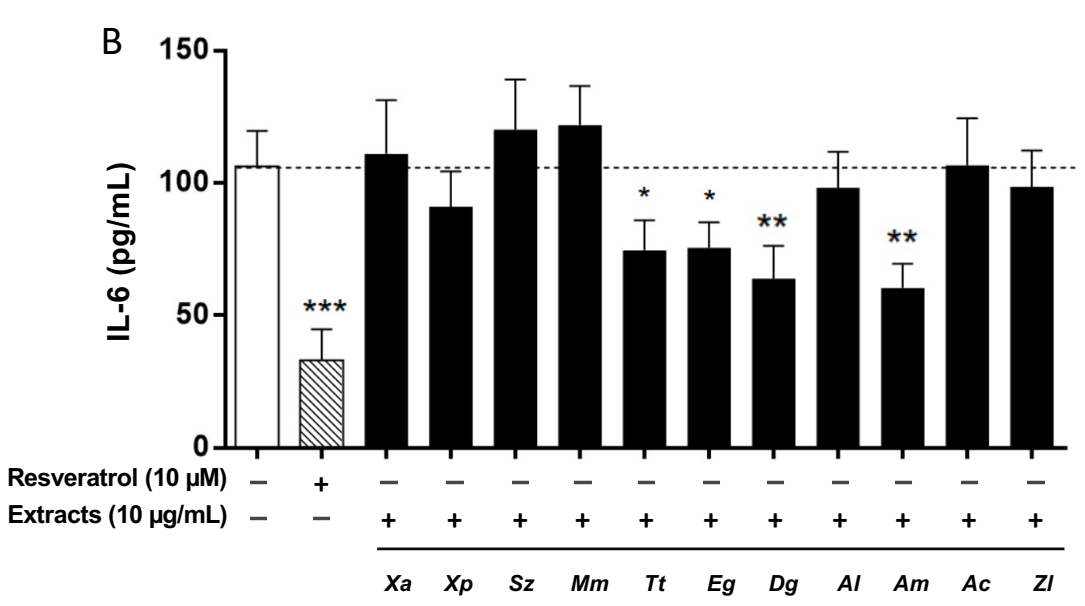

D

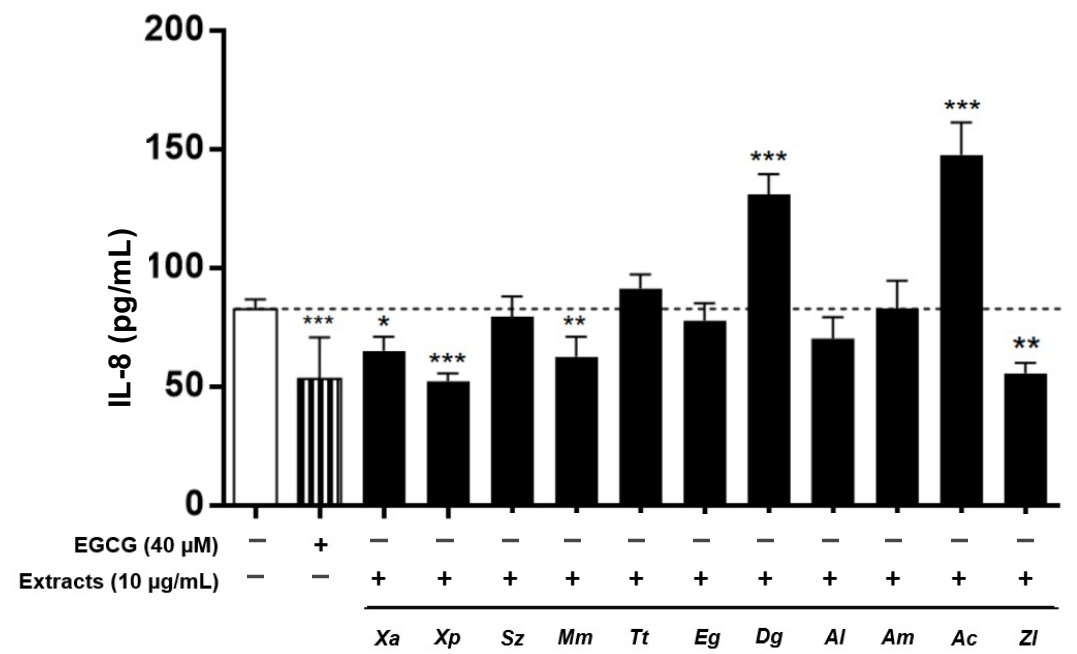

Figure 4. Effects of spice extracts on interleukin-6 (IL-6) and interleukin-8 (IL-8) release by differentiated SW 872 cells. (A) Basal IL-6 content was determined at T0 and T7 ( 1 and 7 days after seeding, respectively) and at OA T7 (after 7-day differentiation with $100 \mu \mathrm{M}$ oleic acid (OA)). (B) OA-differentiated cells were treated with $10 \mu \mathrm{g} / \mathrm{mL}$ spice extracts or the positive controls (10 $\mu \mathrm{M}$ resveratrol or $40 \mu \mathrm{M}$ epigallocatechin gallate (EGCG)). (C) Basal IL-8 content was determined at T0 and T7 (1 and 7 days after seeding, respectively) and at OA T7 (after 7-day differentiation with $100 \mu$ M OA). (D) OAdifferentiated cells were treated with $10 \mu \mathrm{g} / \mathrm{mL}$ spice extracts or the positive controls $(10 \mu \mathrm{M}$ resveratrol or $40 \mu \mathrm{M}$ EGCG). IL- 6 and IL- 8 content in the culture medium was determined after $24 \mathrm{~h}$ incubation. One experiment $(n=3)$ is shown as representative of 3 separate experiments, each in triplicate. Results are shown as mean $\pm \mathrm{SD}$. Data are expressed as $\mathrm{pg} / \mathrm{mL}$. ${ }^{*} p<0.05,{ }^{* *} p<0.01,{ }^{* * *} p<0.001$ (one-way ANOVA multiple comparison). Xa: Xylopia aethiopica; Xp: Xylopia parviflora; Sz: Scorodophloeus zenkeri; Mm: Monodora myristica; Tt: Tetrapleura tetraptera; Eg: Echinops giganteus; Dg: Dichrostachys glomerata; Al: Afrostyrax lepidophyllus; Am: Aframomum melegueta; Ac: Aframomum citratum; Zl: Zanthoxylum leprieurii.

\subsection{Spice Extracts Affect Reactive Oxygen Species Production in Differentiated Adipocytes}

The protective effect of antioxidants on cells is related to their ability to reduce the level of intracellular ROS generation. To assess whether spice extracts could reduce intracellular oxidative stress, intracellular ROS generation was quantified in differentiated SW 872 cells using the $\mathrm{CM}-\mathrm{H}_{2}$ DCFDA assay. Cells were differentiated with OA for seven days and treated or not for another $24 \mathrm{~h}$ with spice extracts before being exposed for $1 \mathrm{~h}$ to $500 \mu \mathrm{M}$ $\mathrm{H}_{2} \mathrm{O}_{2}$. Treatment with $500 \mu \mathrm{M} \mathrm{H}_{2} \mathrm{O}_{2}$ alone produced in a 2.5-fold increase in intracellular ROS levels (Table 2). 
Table 2. Intracellular ROS production in differentiated SW 872 adipocytes: effect of spice extracts.

\begin{tabular}{ccc}
\hline & $\mathbf{H}_{\mathbf{2}} \mathbf{O}_{\mathbf{2}} \mathbf{( 5 0 0 \mu \mathrm { M } )}$ & Relative Intracellular ROS Level (\%) \\
\hline Control & - & $35.9 \pm 0.2^{* * *}$ \\
$\mathrm{H}_{2} \mathrm{O}_{2}(500 \mu \mathrm{M})$ & + & 100 \\
Trolox $(500 \mu \mathrm{M})$ & + & $61.8 \pm 8.6^{* * *}$ \\
Xylopia aethiopica & + & $255.7 \pm 9.3^{* * *}$ \\
Xylopia parviflora & + & $49.6 \pm 3.53^{* *}$ \\
Scorodophloeus zenkeri & + & $94.7 \pm 1.6$ \\
Monodora myristica & + & $60.0 \pm 8.9^{* * *}$ \\
Tetrapleura tetraptera & + & $72.7 \pm 1.5^{* *}$ \\
Echinops giganteus & + & $56.4 \pm 1.2^{* * *}$ \\
Afrostyrax lepidophyllus & + & $75.4 \pm 0.9^{*}$ \\
Dichrostachys glomerata & + & $66.6 \pm 0.6$ \\
Aframomum melegueta & + & $122.5 \pm 9.9^{* *}$ \\
Aframomum citratum & + & $112.8 \pm 0.4$ \\
Zanthoxylum leprieurii & + & $89.9 \pm 3.3$
\end{tabular}

All plant extracts were used at $10 \mu \mathrm{g} / \mathrm{mL}$. Data are expressed as $\%$ of $\mathrm{H}_{2} \mathrm{O}_{2}$-treated cells taken as $100 ;$ mean $\pm \mathrm{SD}$ $n=3$. One experiment $(n=3)$ is shown as representative of 3 separated experiments, each in triplicate. Results are expressed as mean \pm SD. ${ }^{*} p<0.05,{ }^{* *} p<0.01,{ }^{* * *} p<0.001$ (one-way ANOVA multiple comparison).

When cells were pre-treated for $24 \mathrm{~h}$ with spice extracts (all at $10 \mu \mathrm{g} / \mathrm{mL}$ ), ROS production induced by $1 \mathrm{~h}$ treatment with $\mathrm{H}_{2} \mathrm{O}_{2}$ was reduced to a different extent by all spices except $A$. citratum, Z. leprieurii, and S. zenkeri, which were ineffective. Moreover, $X$. aethiopica and A. melegueta extracts significantly increased ROS production (Table 2). In addition, the most effective extracts (X. parviflora, E. giganteus, and D. glomerata) were found to exert their ROS scavenging activity in a concentration-dependent fashion (Figure 5).

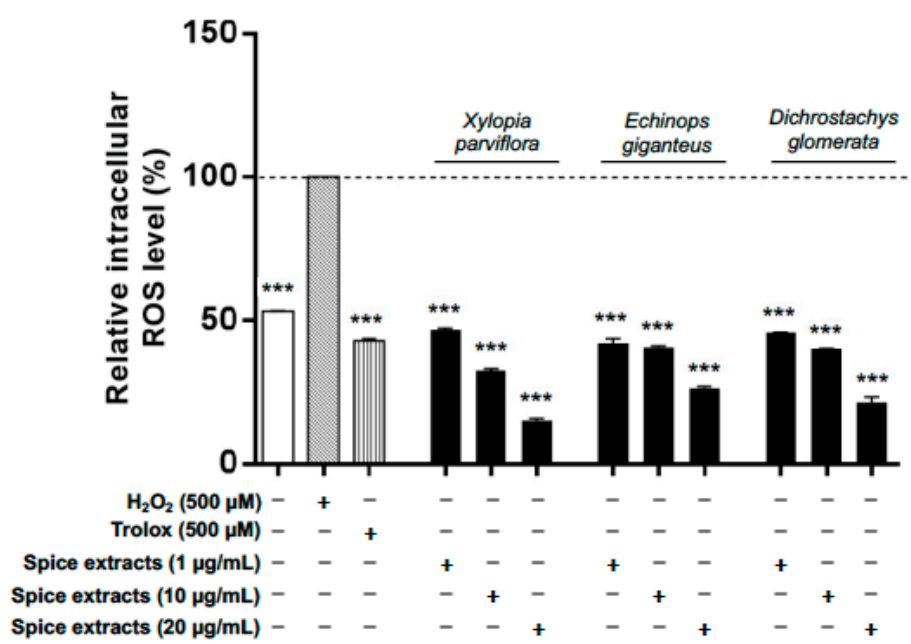

Figure 5. Concentration-dependent modulation of intracellular ROS release in SW 872 cells. The 3 most potent spice extracts were selected to evaluate the dose response. Concentration-dependent reduction of intracellular ROS production in SW 872 cells by selected spice extracts (Xylopia parviflora, Echinops giganteus, and Dichrostachys glomerata). Data are expressed as \% of control taken as 100; mean $\pm \mathrm{SD}, n=3$. One experiment $(n=3)$ is shown as representative of 3 separated experiments, each in triplicate. Results are expressed as mean $\pm \mathrm{SD}$. ${ }^{* * *} p<0.001$ (one-way ANOVA multiple comparison).

\section{Discussion}

Nutraceutical approaches to prevent and treat cardiometabolic conditions are nowadays a relevant and promising research field [18], in some instances taking advantage of knowledge derived from traditional medicine. In the present study, we evaluated the effects of a set of plant extracts used in Cameroon as nutritional spices and medicinal agents $[19,20]$ on cellular events related to the molecular pathophysiology of cardiometabolic diseases. In consideration that ectopic adipose tissue, especially when dysfunctional, is a well-known 
important player in cardiovascular and metabolic diseases [21], in the present study, we selected human SW 872 differentiated adipocytes as the model system [22,23]. SW 872 cells show, under basal conditions, an immature phenotype and constitutively express several genes involved in fatty acid metabolism, such as lipoprotein lipase (LPL), cholesterol ester transfer protein (CETP), cluster of differentiation 36 (CD36), peroxisome proliferatoractivated receptor (PPAR) $\alpha$, PPAR $\gamma$ and LDL receptor-related protein (LRP) [22]. For the purpose of this study, SW 872 were differentiated to mature adipocytes using OA, according to established protocols [9]. We observed an overall inhibitory action across all plant extracts regarding TG content of SW 872 cells since the massive TG accumulation induced by $\mathrm{OA}$ treatment was reduced by $-11 /-18 \%$ by all extracts after $48 \mathrm{~h}$. Consistent with our data, it has been reported that lipid accumulation was significantly decreased in 3T3-L1 adipocytes by resveratrol [24], which was selected here as a positive control. All the tested spice extracts are rich in a variety of primary metabolites (glycerol, fructofuranose, glucopyranose, etc) and secondary metabolites (chlorogenic acid, catechin, pimaric acid, etc.) [5] that orchestrate the observed molecular responses.

The occurrence of some plant specificity in this effect is suggested by our previous observation that Adansonia digitata L. extracts did not affect TG accumulation in differentiated SW 872 adipocytes [8]. The development of obesity is accompanied by adipocyte hypertrophy and hyperplasia [25] leading to excess of lipid accumulation [26], and the observed effects may at least in part explain the actions of some of the tested plants in animal models. For example, extracts from A. melegueta seeds were found to reduce adipose tissue in obese mice [19], and high-carbohydrate and high-fat diet-induced obesity and diabetes in rats were attenuated by T. tetraptera extract [27]. Dysfunctional adipocytes, as observed in T2DM and obesity, also develop reduced glucose uptake [28-30]. In this study, T. tetraptera, A. melegueta and Z. leprieurii increased glucose uptake in a dose-dependent manner. Interestingly, in another in-vitro model, the HepG2 cells, T. tetraptera and A. melegueta, but not Z. leprieurii increased glucose uptake [7], underlining the relationship between the complex molecular composition of the spice extracts, the observed effect and the specificity linked to the tested cell model. In differentiated SW 872 cells, the tested spice extracts do not appear to modulate the Akt upstream pathway whether or not in the presence of insulin, suggesting that they may increase glucose uptake by promoting other molecular events, like glucose transporter translocation to the membrane. Moreover, insulin resistance, glucose uptake impairment and metabolic disfunction appear to be sustained by the secretion from dysfunctional adipocytes of several pro-inflammatory cytokines [31] as well as by the resultant ROS production [1,32]. Based on these considerations, we evaluated the secretory profile of IL-6 and IL-8, two NF-kB-dependent molecular mediators released in the context of chronic inflammation [7]. Among the 11 tested extracts, four (A. melegueta, D. glomerata, T. tetraptera and E. giganteus) were effective in significantly reducing (-29/-43\%) IL-6 release. T. tetraptera, and D. glomerata were also found to similarly reduce IL-6 release by GES-1 gastric epithelial cells [6]. In addition, four spice extracts (X. parviflora, X. aethiopica, M. myristica, and Z. leprieurii) were able to reduce $(-21 /-36 \%)$ IL-8 release, whereas this was markedly increased by D. glomerata and A. citratum. Notably, D. glomerata extract showed a dichotomic effect, reducing IL-6 and increasing IL-8 secretion. It is important to highlight that the release of each cytokine was negatively modulated by fully different sets of plants. Although it is challenging to exactly establish the role of each extract and their metabolites in IL-6 and IL-8 modulation, it is well known that shogaol, gingerol, chlorogenic acid, pimaric acid, and other molecules identified in our extracts [5] are well known inhibitors of NF-kB [14,33-36].

Furthermore, we assessed the effects of treatment with these Cameroonian spice extracts on $\mathrm{H}_{2} \mathrm{O}_{2}$-induced ROS production in differentiated SW 872 cells. All extracts, except A. citratum, Z. leprieurii and S. zenkeri were able to reduce ROS production. X. parviflora, E. giganteus and D. glomerata were the most effective and showed a dose-related activity. These antioxidant effects could be explained by the high content in phenolic compounds 
and the potent in-vitro antioxidant capacity previously reported by our group [7]. ROS production was however increased by X. aethiopica and A. melegueta extracts.

Taken together, the findings of the present study, summarized in Table 3, suggest that each of these spice extracts display a rather peculiar profile of activity on differentiated SW 872 adipocytes. This deserves further exploitation, in order to highlight in a more robust way the peculiar utilization of each spice extract to target specific functions (i.e., antioxidant vs. anti-inflammatory or promoting glucose uptake). Nutraceutical products with these activities may find their application in subjects with obesity, metabolic syndrome, T2DM and the related atherosclerotic cardiovascular disease risk, either alone, especially in milder conditions [37], or in combination with selected drugs in order to avoid drug dosage increase, prevent some adverse effects and increase the overall efficacy $[4,38]$. Interestingly, some pathophysiological mechanisms underlying these conditions, like oxidative stress and chronic low-grade inflammation, do not seem properly managed by the current pharmacology, and thus, well-characterized plant extracts could allow to specifically target them.

Table 3. Summary of the specific effects of the tested Cameroonian spice extracts on differentiated SW 872 adipocytes.

\begin{tabular}{|c|c|c|c|c|c|}
\hline & Triglyceride Reduction & Glucose Uptake Stimulation & $\begin{array}{c}\text { ROS } \\
\text { Production }\end{array}$ & $\begin{array}{c}\text { IL-6 } \\
\text { Reduction }\end{array}$ & $\begin{array}{c}\text { IL-8 } \\
\text { Reduction }\end{array}$ \\
\hline Xylopia aethiopica & $-14.5 \%$ & & $+55.8 \%$ & & $-21.1 \%$ \\
\hline Xylopia parviflora & $-13.8 \%$ & & $-50.5 \%$ & & $-36.8 \%$ \\
\hline Scorodophloeus zenkeri & $-18.5 \%$ & & & & \\
\hline Monodora myristica & $-15.3 \%$ & & $-40 \%$ & & $-24.3 \%$ \\
\hline Tetrapleura tetraptera & $-13.8 \%$ & $+40.8 \%$ & $-27.4 \%$ & $-29.7 \%$ & \\
\hline Echinops giganteus & $-11.3 \%$ & & $-43.6 \%$ & $-29 \%$ & \\
\hline Afrostyrax lepidophyllus & $-16.5 \%$ & & $-24.6 \%$ & & \\
\hline Dichrostachys glomerata & $-17.4 \%$ & & & $-40 \%$ & \\
\hline Aframomum melegueta & $-13 \%$ & $+41.7 \%$ & & $-43.1 \%$ & \\
\hline Aframomum citratum & $-16 \%$ & & & & $-58.6 \%$ \\
\hline Zanthoxylum leprieurii & $-13.4 \%$ & $+56.6 \%$ & & & $-32.7 \%$ \\
\hline
\end{tabular}

This study has some limitations. OA-differentiated SW 872 cells resemble in some respects human adipocytes although this differentiation protocol is associated with peculiar molecular effects related to PPAR $\gamma$ activation, which therefore need to be taken into consideration in the interpretation of the obtained results. It is also important to underline that the extraction protocol utilized in this study [5] may differ from that used by others, making in some cases the comparison with other studies on the same plants difficult. This work, together with the others published in the last years, contributes to define and enrich the study of the biological activities of a set of Cameroonian spices, particularly in the context of dysfunctional adipocyte cell biology.

\section{Conclusions}

The results of this study show that the tested Cameroonian spice extracts display interesting activities on several molecular features of differentiated SW 872 human adipocytes. All extracts were able to reduce TG accumulation, while the ability to promote glucose uptake, reduce pro-inflammatory cytokines release, and counteract ROS production was limited to panels of three to six plant extracts (Table 3). Such variety of effects may be the basis for the development of nutraceutical products with very specific effects or combining more than one extract to achieve complementary effects. Moreover, T. tetraptera stands out as the most versatile plant since it was found to positively modulate most parameters. Since the 11 spice extracts showed rather variable viability profiles, with some extracts being toxic at concentrations just higher than the most effective doses $(10-20 \mu \mathrm{g} / \mathrm{mL})$, a word of caution should be spent regarding the potential toxicity of some plants when used at higher concentrations and/or prolonged treatments. 
The findings of the present study, conducted in a human adipocyte in-vitro model, highlight some potential health properties of these Cameroonian spices and suggest the opportunity of further studies in the context of experimental and human cardiometabolic diseases.

Supplementary Materials: The following are available online at https:/ / www.mdpi.com/article/10 .3390/nu13124271/s1, Figure S1: SW 872 cells viability (MTS assay) after treatment with all extracts; Figure S2: Intracellular complexity of non-differentiated and differentiated SW 872 cells; Figure S3: Glucose uptake in SW 872 cells. Time course (15-60 min) and dose, response to insulin $(10 \mathrm{nM}-1 \mu \mathrm{M})$ of glucose uptake in non-differentiated (A) and differentiated (B) cells.

Author Contributions: Research design: P.M., A.P.A.N., M.D. (Mario Dell'Agli) and A.P.; conducted experiments: A.P.A.N., A.P., L.D.D., C.O., T.N.D., E.C.-M. and S.P.; contributed reagents, materials, analysis tool: S.P., G.M., T.N.D., L.D.D. and A.P.A.N.; analysis and interpretation of data: A.P.A.N., P.M., L.D.D., E.S. and A.P.; writing manuscript: P.M., A.P.A.N. and A.P.; critically read the manuscript: A.D.T., G.A.A., S.T.S., U.V.M., M.D. (Mario Dell'Agli), J.-R.K. and M.D. (Maria Daglia). All authors have read and agreed to the published version of the manuscript.

Funding: This work was supported by funds to P.M. (Transition grant PSR2015-1720PMAGN_01 from Università degli Studi di Milano, Milan, Italy) andand to M.D.A. (personal funds).

Informed Consent Statement: The data presented in this study are available on request from the corresponding authors.

Data Availability Statement: The data presented in this study are available on request from the corresponding authors.

Acknowledgments: APAN is the recipient of a research fellowship from the Italian Ministry of Foreign Affairs and International Cooperation (MAECI), to which the authors are grateful.

Conflicts of Interest: This study is an original research carried out by the mentioned authors and, thus, the authors declare that there is no conflict of interests regarding the publication of this paper.

\section{References}

1. Manna, P.; Jain, S.K. Obesity, Oxidative Stress, Adipose Tissue Dysfunction, and the Associated Health Risks: Causes and Therapeutic Strategies. Metab. Syndr. Relat. Disord. 2015, 13, 423-444. [CrossRef]

2. Ruscica, M.; Gomaraschi, M.; Mombelli, G.; Macchi, C.; Bosisio, R.; Pazzucconi, F.; Pavanello, C.; Calabresi, L.; Arnoldi, A.; Sirtori, C.R.; et al. Nutraceutical approach to moderate cardiometabolic risk: Results of a randomized, double-blind and crossover study with Armolipid Plus. J. Clin. Lipidol. 2014, 8, 61-68. [CrossRef]

3. Cicolari, S.; Pavanello, C.; Olmastroni, E.; del Puppo, M.; Bertolotti, M.; Mombelli, G.; Catapano, A.L.; Calabresi, L.; Magni, P. Interactions of Oxysterols with Atherosclerosis Biomarkers in Subjects with Moderate Hypercholesterolemia and Effects of a Nutraceutical Combination (Bifidobacterium longum BB536, Red Yeast Rice Extract) (Randomized, Double-Blind, PlaceboControlled Study). Nutrients 2021, 13, 427. [CrossRef] [PubMed]

4. Salehi, B.; Ata, A.; Anil Kumar, N.V.; Sharopov, F.; Ramírez-Alarcón, K.; Ruiz-Ortega, A.; Abdulmajid Ayatollahi, S.; Tsouh Fokou, P.V.; Kobarfard, F.; Amiruddin Zakaria, Z.; et al. Antidiabetic Potential of Medicinal Plants and Their Active Components. Biomolecules 2019, 9, 551. [CrossRef] [PubMed]

5. Atchan Nwakiban, A.P.; Sokeng, A.J.; Dell'Agli, M.; Bossi, L.; Beretta, G.; Gelmini, F.; Deutou Tchamgoue, A.; Agbor Agbor, G.; Kuiate, J.R.; Daglia, M.; et al. Hydroethanolic plant extracts from Cameroon positively modulate enzymes relevant to carbohydrate/lipid digestion and cardio-metabolic diseases. Food Funct. 2019, 10, 6533-6542. [CrossRef]

6. Nwakiban, A.P.A.; Fumagalli, M.; Piazza, S.; Magnavacca, A.; Martinelli, G.; Beretta, G.; Magni, P.; Tchamgoue, A.D.; Agbor, G.A.; Kuiaté, J.R.; et al. Dietary Cameroonian Plants Exhibit Anti-Inflammatory Activity in Human Gastric Epithelial Cells. Nutrients 2020, 12, 3787. [CrossRef]

7. Nwakiban, A.P.A.; Cicolari, S.; Piazza, S.; Gelmini, F.; Sangiovanni, E.; Martinelli, G.; Bossi, L.; Carpentier-Maguire, E.; Tchamgoue, A.D.; Agbor, G.; et al. Oxidative Stress Modulation by Cameroonian Spice Extracts in HepG2 Cells: Involvement of Nrf2 and Improvement of Glucose Uptake. Metabolites 2020, 10, 182. [CrossRef]

8. Cicolari, S.; Dacrema, M.; Tsetegho Sokeng, A.J.; Xiao, J.; Atchan Nwakiban, A.P.; Di Giovanni, C.; Santarcangelo, C.; Magni, P.; Daglia, M. Hydromethanolic Extracts from Adansonia digitata L Edible Parts Positively Modulate Pathophysiological. Molecules 2020, 25, 2858. [CrossRef] [PubMed]

9. Guennoun, A.; Kazantzis, M.; Thomas, R.; Wabitsch, M.; Tews, D.; Seetharama Sastry, K.; Abdelkarim, M.; Zilberfarb, V.; Strosberg, A.D.; Chouchane, L. Comprehensive molecular characterization of human adipocytes reveals a transient brown phenotype. J. Transl. Med. 2015, 13, 135. [CrossRef] 
10. Carmel, J.F.; Tarnus, E.; Cohn, J.S.; Bourdon, E.; Davignon, J.; Bernier, L. High expression of apolipoprotein E impairs lipid storage and promotes cell proliferation in human adipocytes. J. Cell Biochem. 2009, 106, 608-617. [CrossRef]

11. Butterweck, V.; Nahrstedt, A. What is the best strategy for preclinical testing of botanicals? A critical perspective. Planta Med. 2012, 78, 747-754. [CrossRef]

12. Kim, Y.M.; Jang, M.S. Anti-obesity effects of Laminaria japonica fermentation on 3T3-L1 adipocytes are mediated by the inhibition of C/EBP-alpha/beta and PPAR-gamma. Cell Mol. Biol. 2018, 64, 71-77. [CrossRef] [PubMed]

13. Sangiovanni, E.; Di Lorenzo, C.; Colombo, E.; Colombo, F.; Fumagalli, M.; Frigerio, G.; Restani, P.; Dell'Agli, M. The effect of in vitro gastrointestinal digestion on the anti-inflammatory activity of Vitis vinifera L. leaves. Food Funct. 2015, 6, $2453-2463$. [CrossRef]

14. Piazza, S.; Pacchetti, B.; Fumagalli, M.; Bonacina, F.; Dell'Agli, M.; Sangiovanni, E. Comparison of Two Ginkgo biloba L. Extracts on Oxidative Stress and Inflammation Markers in Human Endothelial Cells. Mediat. Inflamm. 2019, 2019, 6173893. [CrossRef]

15. Biological Evaluation of Medical Devices-Part 5: Tests for In Vitro Cytotoxicity. Évaluation Biologique des Dispositifs Médicaux-Partie 5: Essais Concernant la Cytotoxicité In Vitro, Third Edition. International Organization for Standardization. Posted June 1. 2009. Available online: https://nhiso.com/wp-content/uploads/2018/05/ISO-10993-5-2009.pdf (accessed on 25 November 2021).

16. Krycer, J.R.; Quek, L.E.; Francis, D.; Zadoorian, A.; Weiss, F.C.; Cooke, K.C.; Nelson, M.E.; Diaz-Vegas, A.; Humphrey, S.J.; Scalzo, R.; et al. Insulin signaling requires glucose to promote lipid anabolism in adipocytes. J. Biol. Chem. 2020, 295, 13250-13266. [CrossRef]

17. Shoshani, O.; Livne, E.; Armoni, M.; Shupak, A.; Berger, J.; Ramon, Y.; Fodor, L.; Gilhar, A.; Peled, I.J.; Ullmann, Y. The effect of interleukin-8 on the viability of injected adipose tissue in nude mice. Plast. Reconstr. Surg. 2005, 115, 853-859. [CrossRef] [PubMed]

18. Liu, S.; Chang, X.; Yu, J.; Xu, W. Cherry Polyphenol Reduces High-Fat Diet-Induced Obesity in C57BL/6 Mice by Mitigating Fat Deposition, Inflammation, and Oxidation. J. Agric. Food Chem. 2020, 68, 4424-4436. [CrossRef] [PubMed]

19. Kuete, V.; Krusche, B.; Youns, M.; Voukeng, I.; Fankam, A.G.; Tankeo, S.; Lacmata, S.; Efferth, T. Cytotoxicity of some Cameroonian spices and selected medicinal plant extracts. J. Ethnopharmacol. 2011, 134, 803-812. [CrossRef] [PubMed]

20. Hattori, H.; Mori, T.; Shibata, T.; Kita, M.; Mitsunaga, T. 6-Paradol Acts as a Potential Anti-obesity Vanilloid from Grains of Paradise. Mol. Nutr. Food Res. 2021, 65, e2100185. [CrossRef]

21. Neeland, I.J.; Ross, R.; Després, J.P.; Matsuzawa, Y.; Yamashita, S.; Shai, I.; Seidell, J.; Magni, P.; Santos, R.D.; Arsenault, B.; et al. Visceral and ectopic fat, atherosclerosis, and cardiometabolic disease: A position statement. Lancet Diabetes Endocrinol. 2019, 7, 715-725. [CrossRef]

22. Wassef, H.; Bernier, L.; Davignon, J.; Cohn, J.S. Synthesis and secretion of apoC-I and apoE during maturation of human SW872 liposarcoma cells. J. Nutr. 2004, 134, 2935-2941. [CrossRef] [PubMed]

23. Lehrke, M.; Lazar, M.A. The many faces of PPARgamma. Cell 2005, 123, 993-999. [CrossRef] [PubMed]

24. Rayalam, S.; Yang, J.Y.; Ambati, S.; Della-Fera, M.A.; Baile, C.A. Resveratrol induces apoptosis and inhibits adipogenesis in 3T3-L1 adipocytes. Phytother. Res. 2008, 22, 1367-1371. [CrossRef]

25. Nishimura, S.; Manabe, I.; Nagasaki, M.; Hosoya, Y.; Yamashita, H.; Fujita, H.; Ohsugi, M.; Tobe, K.; Kadowaki, T.; Nagai, R.; et al. Adipogenesis in obesity requires close interplay between differentiating adipocytes, stromal cells, and blood vessels. Diabetes 2007, 56, 1517-1526. [CrossRef]

26. Kim, M.R.; Kim, J.W.; Park, J.B.; Hong, Y.K.; Ku, S.K.; Choi, J.S. Anti-obesity effects of yellow catfish protein hydrolysate on mice fed a 45\% kcal high-fat diet. Int. J. Mol. Med. 2017, 40, 784-800. [CrossRef]

27. Kuate, D.; Kengne, A.P.; Biapa, C.P.; Azantsa, B.G.; Abdul Manan Bin Wan Muda, B. Tetrapleura tetraptera spice attenuates high-carbohydrate, high-fat diet-induced obese and type 2 diabetic rats with metabolic syndrome features. Lipids Health Dis. 2015, 14, 50. [CrossRef]

28. Furukawa, S.; Fujita, T.; Shimabukuro, M.; Iwaki, M.; Yamada, Y.; Nakajima, Y.; Nakayama, O.; Makishima, M.; Matsuda, M.; Shimomura, I. Increased oxidative stress in obesity and its impact on metabolic syndrome. J. Clin. Investig. 2004, 114, $1752-1761$. [CrossRef] [PubMed]

29. Cawthorn, W.P.; Sethi, J.K. TNF-alpha and adipocyte biology. FEBS Lett. 2008, 582, 117-131. [CrossRef]

30. Zhang, W.Y.; Lee, J.J.; Kim, I.S.; Kim, Y.; Myung, C.S. Stimulation of glucose uptake and improvement of insulin resistance by aromadendrin. Pharmacology 2011, 88, 266-274. [CrossRef]

31. Kobashi, C.; Asamizu, S.; Ishiki, M.; Iwata, M.; Usui, I.; Yamazaki, K.; Tobe, K.; Kobayashi, M.; Urakaze, M. Inhibitory effect of IL-8 on insulin action in human adipocytes via MAP kinase pathway. J. Inflamm. 2009, 6, 25. [CrossRef]

32. Issa, N.; Lachance, G.; Bellmann, K.; Laplante, M.; Stadler, K.; Marette, A. Cytokines promote lipolysis in 3T3-L1 adipocytes through induction of NADPH oxidase 3 expression and superoxide production. J. Lipid Res. 2018, 59, 2321-2328. [CrossRef]

33. Suh, S.J.; Kwak, C.H.; Chung, T.W.; Park, S.J.; Cheeeei, M.; Park, S.S.; Seo, C.S.; Son, J.K.; Chang, Y.C.; Park, Y.G.; et al. Pimaric acid from Aralia cordata has an inhibitory effect on TNF- $\alpha$-induced MMP-9 production and HASMC migration via down-regulated NF-kB and AP-1. Chem. Biol. Interact. 2012, 199, 112-119. [CrossRef] [PubMed]

34. Saha, A.; Blando, J.; Silver, E.; Beltran, L.; Sessler, J.; DiGiovanni, J. 6-Shogaol from dried ginger inhibits growth of prostate cancer cells both in vitro and in vivo through inhibition of STAT3 and NF-kB signaling. Cancer Prev. Res. (Phila) 2014, 7, 627-638. [CrossRef] 
35. Liang, N.; Sang, Y.; Liu, W.; Yu, W.; Wang, X. Anti-Inflammatory Effects of Gingerol on Lipopolysaccharide-Stimulated RAW 264.7 Cells by Inhibiting NF-кB Signaling Pathway. Inflammation 2018, 41, 835-845. [CrossRef] [PubMed]

36. Ruifeng, G.; Yunhe, F.; Zhengkai, W.; Ershun, Z.; Yimeng, L.; Minjun, Y.; Xiaojing, S.; Zhengtao, Y.; Naisheng, Z. Chlorogenic acid attenuates lipopolysaccharide-induced mice mastitis by suppressing TLR4-mediated NF-kB signaling pathway. Eur. J. Pharm. 2014, 729, 54-58. [CrossRef]

37. Dinda, B.; Dinda, M.; Roy, A.; Dinda, S. Dietary plant flavonoids in prevention of obesity and diabetes. Adv. Protein Chem. Struct. Biol. 2020, 120, 159-235. [CrossRef]

38. Samson, S.L.; Garber, A.J. Metabolic syndrome. Endocrinol. Metab. Clin. 2014, 43, 1-23. [CrossRef] [PubMed] 